\title{
Evaluation of Serum Complement Component 1Q Subcomponent C (C1qC) as a Marker for Tuberculosis
}

\author{
Ajay Kumar ${ }^{1}$, Kiran Chawla², Haritha Madigubba ${ }^{3}$, Rupesh Thakur ${ }^{4}$, Dakshina Bisht ${ }^{5}$ \\ ${ }^{1}$ PhD Scholar, Department of Microbiology, Santosh Medical College and Hospital, \\ Santosh Deemed to be University, NCR Delhi, India. \\ 2Professor \& Head, Department of Microbiology, Kasturba Medical College, \\ Manipal Academy of Higher Education, Manipal, Karnataka, India. \\ ${ }^{3}$ Post Graduate Student, Department of Microbiology, Kasturba Medical College, \\ Manipal Academy of Higher Education, Manipal, Karnataka, India. \\ ${ }^{4}$ Associate Professor, School of Life \& Allied Science, ITM University, Atal Nagar, Raipur, Chattishgarh, India. \\ ${ }^{5}$ Professor and Head, Department of Microbiology, Santosh Medical College and Hospital, \\ Santosh Deemed to be University, NCR Delhi, India.
}

\section{ABSTRACT}

\section{BACKGROUND}

Despite several efforts, tuberculosis (TB) continues to be a global concern. For proper management of TB, more sensitive and specific biomarkers for early and accurate diagnosis of TB are still required. Blood based host markers are more appealing as an alternate to sputum-based diagnostics. Thus, in the present study, we evaluated the potential of Serum Complement Component $1 \mathrm{Q}$ Subcomponent $\mathrm{C}(\mathrm{C} 1 \mathrm{qC})$ as a marker for tuberculosis.

\section{METHODS}

Serum samples from 84 subjects which included 39 smear positive pulmonary TB patients and 45 controls (Latent $T B n=15$, Healthy $n=15$ and patients with respiratory diseases other than $\mathrm{TB} n=15$ ) were collected and Enzyme Linked Immunosorbent Assay was performed to estimate the serum $\mathrm{C} 1 \mathrm{qC}$ levels.

\section{RESULTS}

The mean $( \pm \mathrm{SD})$ serum $\mathrm{C} 1 \mathrm{qC}$ levels in $\mathrm{TB}$, Healthy, Latent $\mathrm{TB}$ and patients with respiratory diseases other than TB was found to be $21.80( \pm 4.39), 13.64( \pm 1.32)$, $15.18( \pm 1.29)$ and $17.31( \pm 1.87) \mathrm{pg} / \mathrm{ml}$ respectively. The AUC of serum C1qC to discriminate TB patients from controls was found to be 0.924 (95\% CI, 0.869-0.978). At an optimal cut-off value of $16.99 \mathrm{pg} / \mathrm{ml}$, the sensitivity and specificity of serum C1qC to discriminate TB from controls was found to be $84.62 \%$ (95\% CI, $69.47 \%$ $94.14 \%)$ and $84.44 \%$ (95\% CI, 70.54\%-93.51\%) respectively with a likelihood ratio of 5.44 .

\section{CONCLUSIONS}

The levels of serum $\mathrm{C} 1 \mathrm{qC}$ in $\mathrm{TB}$ patients was found to be significantly higher than controls. $\mathrm{C} 1 \mathrm{qC}$ seems to be a promising marker for the diagnosis and therapeutic monitoring of TB, though further elaborate studies in larger cohorts are required to establish the role for $\mathrm{C} 1 \mathrm{qC}$ in the diagnosis and therapeutic monitoring of $\mathrm{TB}$.
Corresponding Author: Dr. Dakshina Bisht, Professor \& Head, Department of Microbiology, Santosh Medical College and Hospital, Santosh Deemed to be University, NCR Delhi, India.

E-mail: dakshinabisht@gmail.com

DOI: $10.14260 / j e m d s / 2019 / 571$

Financial or Other Competing Interests: None.

How to Cite This Article:

Kumar A, Chawla K, Madigubba $\mathrm{H}$, et al. Evaluation of serum complement component 1 q subcomponent $C(C 1 Q C)$ as a marker for tuberculosis. J. Evolution Med. Dent. Sci. 2019;8(33):2624-2628, DOI: $10.14260 / j e m d s / 2019 / 571$

Submission 20-04-2019, Peer Review 04-08-2019, Acceptance 10-08-2019, Published 19-08-2019.

\section{KEY WORDS}

Biomarker, Complement, C1qC, ELISA, Tuberculosis 


\section{BACKGROUND}

Despite worldwide efforts, tuberculosis continues to be a global health care concern. According to World Health Organization (WHO) report in 2017, approximately 10 million people developed TB. Further 1.7 billion of the world total population are estimated to have Latent TB and are at risk of developing active TB during their lifetime. ${ }^{1}$ Rapid diagnosis and appropriate treatment is important for controlling the interhuman transmission of TB bacilli. The diagnosis of TB is primarily based on smear microscopy, which has poor sensitivity and is inappropriate for therapeutic monitoring as it cannot differentiate viable or dead bacilli.2,3 Sputum culture is the current Gold standard, but requires several weeks and is laborious. ${ }^{4}$ Recently developed GeneXpert MTB/RIF assays has shown promises, but has low sensitivity in smear-negative samples, cannot distinguish live from nonviable MTB, has a short shelf life, is expensive and requires a stable electric supply and a critical temperature ceiling. ${ }^{5}$ One of the major drawbacks of sputum based diagnosis is that it requires MTBpositive sputum which is very difficult to get in cases of HIVTB co-infection, diabetes and paediatric patients. It is also observed that after few weeks of treatment the volume and quality of sputum decline in many patients which results in poor therapeutic monitoring. ${ }^{6}$ Further sputum-based diagnosis is not applicable in extrapulmonary TB where invasive techniques are applied for the collection of sitespecific samples. Thus; to fill the void of rapid TB diagnostics discovery of more sensitive and specific biomarkers which are more accessible and affordable is still desirable. In the above context blood-based host markers are more appealing as an alternate to sputum-based diagnostics. Since blood is relatively easy to collect and remains available throughout the course of treatment; blood-based markers seem more promising to be translated as a point of care test. Earlier blood gene expression studies have highlighted compliment as candidate biomarker for active TB even in the presence of HIV co-infection..$^{7-9}$ A recent study reported increased expression of $\mathrm{C} 1 \mathrm{qC}$ in peripheral blood during active $\mathrm{TB}$ and $\mathrm{C} 1 \mathrm{QC}$ has better diagnostic value than other inflammatory markers like IL- 6 and TNF- $\alpha .{ }^{10}$ Thus, in the present study, we evaluated the potential of serum $\mathrm{C} 1 \mathrm{qC}$ level to discriminate active $\mathrm{TB}$ patients from controls comprising of healthy, latent $\mathrm{TB}$ and patients with respiratory diseases other than TB by Enzyme linked Immunosorbent Assay (ELISA) in Indian cohort.

\section{METHODS}

\section{Study Setting and Subjects}

A cross sectional, prospective study was performed at the Department of Microbiology at a tertiary care centre in India for the duration of 1 year from January 2018 to December 2018 after obtaining approval from Institutional Research and Ethics Committee. Present study involved 4 study groups; Tuberculosis patients (TB, $n=39$ ): Sputum samples (One spot and one early morning sputum) were collected from suspected TB patients, smear was prepared and were stained with $0.3 \%$ Auramine phenol 0 for 10 minutes, then decolorized with $1 \%$ acid alcohol solution for 2 minutes and were finally counter stained with $0.1 \%$ potassium permanganate for 1 minute. Stained smears were examined using LED-FM as per RNTCP guidelines. All newly diagnosed smear positive pulmonary Tuberculosis patients were enrolled for the study. Blood samples from patients were collected prior to initiation of antitubercular treatment. Respiratory diseases other than TB (ORD, $n=15$ ): patients admitted with respiratory illness negative for TB by smear microscopy and GeneXpert. For selection of latent TB $(n=15)$ and healthy $(n=15)$, blood samples from household contacts $(n=51)$ of smear positive pulmonary tuberculosis patients was screened for interferon$\gamma($ IFN- $\gamma$ ) response to TB antigens. Briefly $1 \mathrm{ml}$ of whole blood was collected in a negative control NIL tube (coated with saline), a TB antigen tube (Coated with ESAT-6, CFP-10 and TB7.7) and positive control Mitogen tube (coated with Phytohemagglutinin, PHA) from each participant and contents in the tubes were mixed thoroughly by shaking firmly for 10 times and then the tubes were incubated at $37^{\circ} \mathrm{C}$ in an upright position for 16-24 hours. Harvesting of plasma was performed by centrifuging the tubes for 15 minutes at $3000 \mathrm{~g}$. Human IFN$\gamma$ ELISA was performed from the harvested plasma using QuantiFERON-TB Gold ELISA kit (Cellestis Limited, Carnegie, Victoria, Australia) following manufacturer's guidelines and Optical Density (O.D) was measured at $450 \mathrm{~nm}$ using a micro plate reader. The raw data were analysed using the QFT Analysis Software (Cellestis). All samples showing $\geq 0.35 \mathrm{IU} / \mathrm{ml}$ and $\geq 25 \%$ of the negative control value were considered positive, whereas the samples showing $<0.35$ IU $/ \mathrm{ml}$ of IFN $-\gamma$ or $\geq 0.35 \mathrm{IU} / \mathrm{ml}$ of IFN- $\gamma$ and $<25 \%$ of the negative control value were considered negative. When the mitogen-negative control value was $<0.5 \mathrm{IU} / \mathrm{ml}$ the test results were considered inconclusive. The contacts which were found positive for IFN$\gamma$ response were enrolled as latent TB $(n=15)$ whereas those who were found negative were enrolled as healthy $(n=15)$. Patients with HIV infection, those on immunosuppressive drugs and ATT treatment were excluded from the study.

\section{Collection of Samples}

Blood samples (2-5 ml) from each subject from aforementioned four groups were collected in vacutainers and was incubated at $37^{\circ} \mathrm{C}$ for 1 hour, followed by 1 hour at $4^{\circ} \mathrm{C}$ and was centrifuged at $1600 \mathrm{~g}$ for 5 minutes and the supernatant was collected as serum and stored at $-80^{\circ} \mathrm{C}$ until use.

To determine the serum Complement $\mathrm{C} 1 \mathrm{q}$ subcomponent subunit C (C1qC) levels standard sandwich ELISA was performed using kit from Biospes Co., Ltd (Chongqing, China) following manufacturer's guidelines. Briefly $50 \mu \mathrm{l}$ of diluted standards ( $60 \mathrm{pg} / \mathrm{ml}, 40 \mathrm{pg} / \mathrm{ml}, 20 \mathrm{pg} / \mathrm{ml}, 10 \mathrm{pg} / \mathrm{ml}, 5 \mathrm{pg} / \mathrm{ml}$ ) and diluted serum samples $(10 \mu \mathrm{l}$ serum in $40 \mu \mathrm{l}$ sample diluent buffer) were added to the wells of a 96 -well plate precoated with the purified anti-C1qC antibody and the plate was incubated at $37^{\circ} \mathrm{C}$ for 30 minutes. The plate was washed 5 times using wash buffer (kit component 4, diluted 1:30 in distilled water) and $50 \mu \mathrm{l}$ of HRP conjugated anti- C1qC antibody was added to each well (except the control well) and the plate was incubated at $37^{\circ} \mathrm{C}$ for 30 minutes and unbound conjugates were removed by washing the plate by wash buffer. Subsequently $50 \mu \mathrm{l}$ each TMB substrate A and B was added to the wells and the plate was vortexed gently for 30 seconds and was incubated in dark at $37^{\circ} \mathrm{C}$ for 15 minutes. Finally, $50 \mu$ l of stop solution was added to each well, mixed thoroughly and Optical Density (OD) was read at $450 \mathrm{~nm}$. The concentration of $\mathrm{C} 1 \mathrm{qC}$ in each sample was calculated by generating a standard calibrator curve. 


\section{Statistical Analysis}

Statistical analysis was performed using the Graph Pad Prism 5 . Continuous variables are presented as the mean \pm standard deviation (SD) or median (range); categorical variables are presented as percentages. One-way ANOVA with post hoc Tukey's multiple comparison tests was performed to compare the differences between means of $\mathrm{C} 1 \mathrm{qC}$ level among different study groups. Receiver operating characteristic (ROC) analysis was performed to assess the sensitivity and specificity of C1q as biomarker and was expressed as Area under the Curve (AUC). For all statistical analysis the level of significance was set at $\mathrm{p}<0.05$.

\section{RESULTS}

A total of 84 participants comprising 39 smear positive TB patients, 15 LTB (QFT positive), 15 healthy (QFT negative) and 15 patients with respiratory diseases other than TB (ORD) were enrolled in the present study. Mean age \pm SD of the patient was found to be $42.95 \pm 13.72$. Forty-four among them were male and 40 were female. A detailed description of the demographic details of the patients is given in Table 1 . The mean $( \pm \mathrm{SD}$ ) serum C1qC levels in TB, healthy, LTB and patient with respiratory diseases other than TB was found to be 21.80 $( \pm 4.39), 13.64( \pm 1.32), 15.18( \pm 1.29)$ and $17.31( \pm 1.87) \mathrm{pg} / \mathrm{ml}$ respectively. A detailed description of serum $\mathrm{C} 1 \mathrm{qC}$ levels in each group is shown in Figure 1. The analysis of variance showed that the levels of serum $\mathrm{C} 1 \mathrm{qC}$ in $\mathrm{TB}$ patients was found significantly higher than the controls comprising of LTB, healthy and ORD $(F(3,80)=31.09,<0.001)$. Post Hoc comparison using Tukey's multiple comparison test showed that mean of $\mathrm{C} 1 \mathrm{qC}$ levels in $\mathrm{TB}$ patients was significantly different from other study groups though the mean $\mathrm{C} 1 \mathrm{qC}$ difference was not significant when LTB was compared with healthy and ORD. A detailed description of Tukey's multiple comparison tests is summarized in Table 2. On ROC analysis (Figure: 2) the AUC value for serum C1qC to discriminate TB patients from controls (Healthy, LTB and ORD) was found to be 0.924 (95\% CI, 0.869-0.978) with a standard error 0.028 and $\mathrm{p}<0.001$. At an optimal cut-off of $16.99 \mathrm{pg} / \mathrm{ml}$ the sensitivity and specificity of serum $\mathrm{C} 1 \mathrm{qC}$ to discriminate $\mathrm{TB}$ from controls was found to be $84.62 \%$ (95\% CI, $69.47 \%$ $94.14 \%$ ) and $84.44 \%$ (95\% CI, 70.54\%-93.51\%) respectively, with a likelihood ratio of 5.44. Further AUC of serum C1qC levels to discriminated TB from LTB, healthy and patients with respiratory diseases other than TB was found to be 0.950 , 0.995 and 0.826 respectively. A detailed ROC analysis of serum $\mathrm{C} 1 \mathrm{qC}$ to discriminate different study groups is summarized in Table 3.

\begin{tabular}{|c|c|c|c|c|}
\hline & $\begin{array}{c}\text { Tuberculosis } \\
(\mathbf{n}=39)\end{array}$ & $\begin{array}{c}\text { Latent TB } \\
(\mathbf{n = 1 5 )}\end{array}$ & $\begin{array}{c}\text { Healthy } \\
(\mathbf{n = 1 5 )}\end{array}$ & $\begin{array}{c}\text { Respiratory } \\
\text { Disease } \\
\text { other than } \\
\text { TB (n=15) }\end{array}$ \\
\hline Age ,Mean \pm SD & $44.23 \pm 15.42$ & $40.80 \pm 12.37$ & $40.67 \pm 9.32$ & $44.07 \pm 14.61$ \\
\hline $\begin{array}{c}\text { Gender; Male } \\
\text { Female }\end{array}$ & $26(66.67 \%)$ & $06(40 \%)$ & $04(26.67 \%)$ & $08(53.33 \%)$ \\
\hline \multicolumn{6}{|c|}{ Table 1. A Detailed Demographic Description of Enrolled Participants } \\
\hline
\end{tabular}

\begin{tabular}{|c|c|c|c|c|c|}
\hline & $\begin{array}{c}\text { Mean } \\
\text { Diff. }\end{array}$ & $\mathbf{q}$ & $\begin{array}{c}\text { Significant? } \\
p<0.05 ?\end{array}$ & Summary & $\begin{array}{c}95 \% \text { CI of } \\
\text { diff }\end{array}$ \\
\hline $\begin{array}{c}\text { Tuberculosis } \\
\text { vs } \\
\text { Latent TB } \\
\end{array}$ & 6.625 & 9.585 & Yes & *** & 4.054 to 9.196 \\
\hline $\begin{array}{c}\text { Tuberculosis } \\
\text { vs } \\
\text { Healthy }\end{array}$ & 8.168 & 11.82 & Yes & *** & 5.597 to 10.74 \\
\hline $\begin{array}{c}\text { Tuberculosis } \\
\text { vs } \\
\text { Respiratory diseases } \\
\text { other than TB } \\
\end{array}$ & 4.491 & 6.498 & Yes & *** & 1.920 to 7.062 \\
\hline $\begin{array}{c}\text { Latent TB } \\
\text { vs } \\
\text { Healthy } \\
\end{array}$ & 1.543 & 1.857 & No & ns & $\begin{array}{l}-1.547 \text { to } \\
4.633\end{array}$ \\
\hline $\begin{array}{c}\text { Latent TB } \\
\text { vs } \\
\text { Respiratory diseases } \\
\text { other than TB } \\
\end{array}$ & -2.134 & 2.569 & No & ns & $\begin{array}{c}-5.224 \text { to } \\
0.9559\end{array}$ \\
\hline $\begin{array}{c}\text { Healthy } \\
\text { vs } \\
\text { Respiratory diseases } \\
\text { other than TB } \\
\end{array}$ & -3.677 & 4.426 & Yes & * & $\begin{array}{c}-6.767 \text { to }- \\
0.5868\end{array}$ \\
\hline
\end{tabular}

Table 2. Tukey's Multiple Comparison Test to Compare the Difference of Mean C1qC Levels among Different Study Groups

\begin{tabular}{|c|c|c|c|c|}
\hline $\begin{array}{c}\text { Tuberculosis } \\
\text { Vs }\end{array}$ & $\begin{array}{c}\text { Area Under } \\
\text { Curve }\end{array}$ & $\begin{array}{c}\text { Standard } \\
\text { Error }\end{array}$ & $\mathbf{9 5 \%}$ CI & $\boldsymbol{p}$ Value \\
\hline Controls & 0.924 & 0.028 & $0.869-0.979$ & $<0.001$ \\
\hline Latent TB & 0.950 & 0.026 & $0.898-1.003$ & $<0.001$ \\
\hline $\begin{array}{c}\text { Respiratory diseases } \\
\text { other than TB }\end{array}$ & 0.826 & 0.058 & $0.712-0.939$ & $<0.00024$ \\
\hline Healthy & 0.996 & 0.005 & $0.985-1.006$ & $<0.001$ \\
\hline \multicolumn{6}{|c|}{ Table 3. Performance of Serum C1qC Levels to Discriminate } \\
TB from Other Study Groups \\
\hline
\end{tabular}
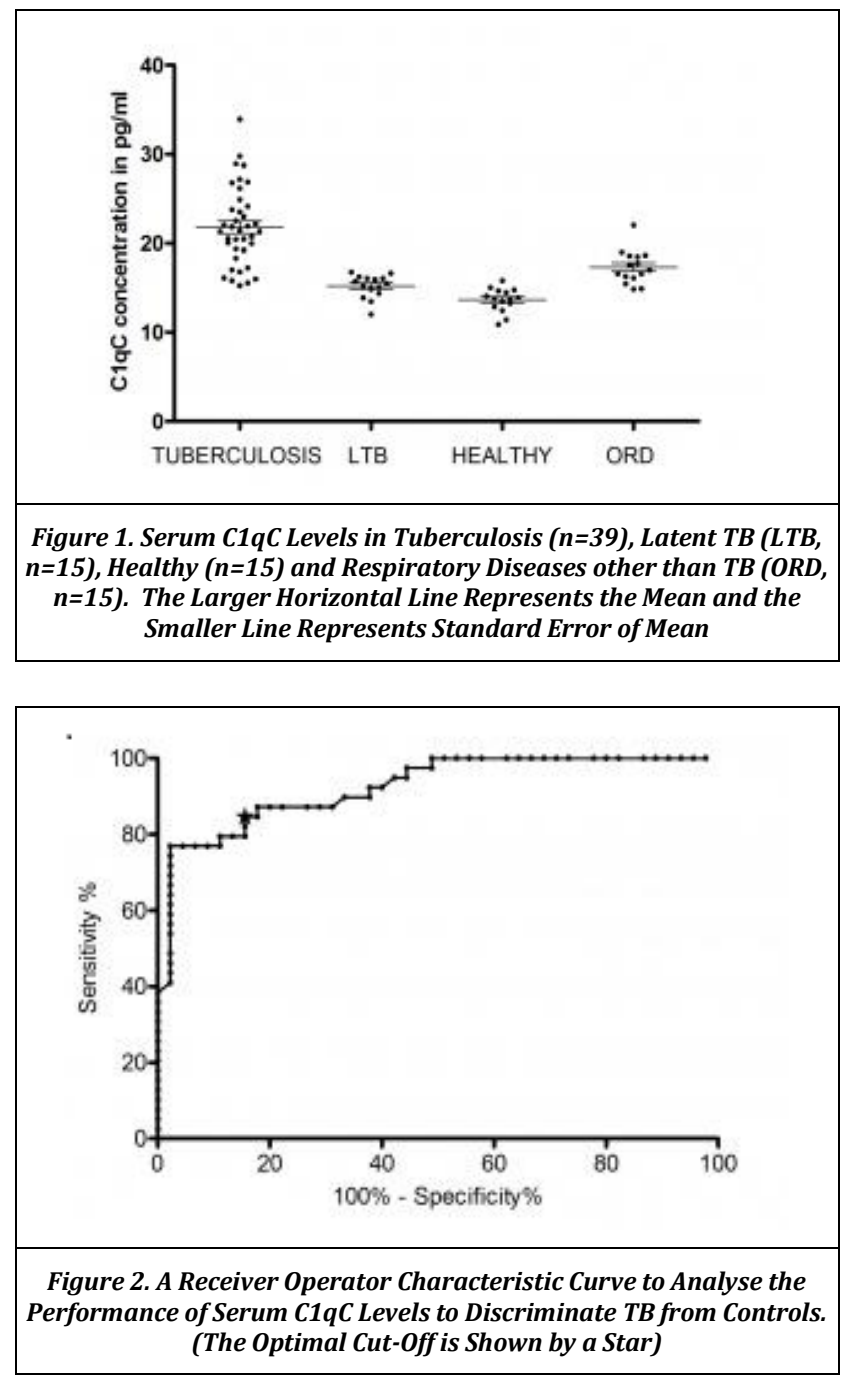


\section{DISCUSSION}

Tuberculosis is a global health care concern. Although TB biomarker research is an area of high activity the results so far has limited success. There is an urgent need to identify non sputum-based biomarkers that can be utilized for rapid diagnosis of Tuberculosis and initiate therapy on the same day. Complement system is an integral part of the host's immune response which plays a major role in the elimination of pathogens by microbial lysis, opsonization and chemotaxis. ${ }^{11,12}$ There are increasing evidences which indicate the role of the complement system in generating protective immune response during mycobacterial infection. ${ }^{13-15} \mathrm{~A}$ blood transcriptomic study reported abundance of transcripts representing the classical compliments pathway in active TB patients in comparison to those with subclinical stages of the disease. ${ }^{9}$ Further on analysing publicly available blood gene expression microarray data of TB patients in comparison with latent $\mathrm{TB}$ or other lung diseases complement gene $\mathrm{C} 1 \mathrm{QC}$ transcripts were observed more than 2 fold higher in TB patients in $78 \%(7 / 9)$ of the studies. ${ }^{16} \mathrm{C} 1 \mathrm{QC}$ encodes for Cchain polypeptide of serum complement subcomponent $\mathrm{C} 1 \mathrm{q}$, which associates with $\mathrm{C} 1 \mathrm{r}$ and $\mathrm{C} 1 \mathrm{~s}$ to yield the first component of the classical complement system. C1q is composed of 18 polypeptide chains which include $6 \mathrm{~A}$-chains, $6 \mathrm{~B}$-chains, and 6 C-chains. ${ }^{17}$ Validation of identified transcriptomic markers at protein level is important to assess their applicability in clinical practice. Thus, in the present study we validated diagnostic potential of $\mathrm{C} 1 \mathrm{qC}$ as a biomarker for active $\mathrm{TB}$ at the protein level in serum.

A recent analysis in three independent cohorts from South Africa, Gambia and Ethiopia using upregulation of complement C1q C-chain and down regulation of T-cell receptor alpha variable gene 27 (TRAV27) transcripts in blood as a predictive marker for TB progression reported an AUC $>0.76$ on all three sites. ${ }^{18}$ In the present study AUC of serum $\mathrm{C} 1 \mathrm{qC}$ to discriminate TB patients from controls (Healthy, LTB and ORD), Healthy, Latent TB, and ORD was found to be $0.92,0.99,0.95$, and 0.82 respectively. Cai et al. in a recent study exploring the potential of plasma $\mathrm{C} 1 \mathrm{qC}$ levels to discriminate TB from healthy, Latent TB and non-TB pleural effusion patients reported AUC (95\% CI) $0.76(0.63-0.90), 0.86(0.77-0.96)$ and $0.91(0.83-0.98)$ respectively which further supports the findings of the present study. ${ }^{10}$ One of the major limitations of the present study was its limited sample size. Further, previously published data reported a rapid decrease in C1qm RNA expression levels following Anti-tubercular treatment (ATT).Cliff et al. ${ }^{8}$ reported a decrease in blood $\mathrm{C} 1 \mathrm{qC}$ genes after 1 week treatment; Cai et al. ${ }^{10}$ reported a significant decrease in the expression of the $\mathrm{C} 1 \mathrm{qC}$ genes at 3 months of ATT and decrease in C1qC protein in peripheral blood at 6 months; whereas Lubbers et al. ${ }^{16}$ reported a gradual decrease in protein level until 6 months. Thus, evaluating serum C1qC levels during ATT might have provided much better insight of the biomarker potential of $\mathrm{C} 1 \mathrm{qC}$ in the present study.

\section{CONCLUSIONS}

The levels of serum $\mathrm{C} 1 \mathrm{qC}$ in $\mathrm{TB}$ patients was found to be significantly higher than the controls. $\mathrm{C} 1 \mathrm{qC}$ seems to be a promising biomarker for $\mathrm{TB}$, though further elaborate studies in larger cohorts are required to establish the role of $\mathrm{C} 1 \mathrm{qC}$ in diagnosis and therapeutic monitoring of TB.

\section{REFERENCES}

[1] World Health Organization. Global tuberculosis report 2018.

https://www.who.int/tb/publications/global_report/en/

[2] Getahun H, Gunneberg C, Granich R, et al. HIV infection associated tuberculosis: the epidemiology and the response. Clin Infect Dis 2010;50(Suppl 3):S201-7.

[3] Steingart KR, Ramsay A, Pai M. Optimizing sputum smear microscopy for the diagnosis of pulmonary tuberculosis. Expert Rev Anti Infect Ther 2007;5(3):327-31.

[4] Lagrange PH, Thangaraj SK, Dayal R, et al. A toolbox for tuberculosis diagnosis: an Indian multicentric study (2006-2008): microbiological results. PLoS One 2012;7(8):e43739.

[5] World Health Organization. Xpert MTB/RIF implementation manual: technical and operational 'howto': practical considerations. World Health Organization, 2014.

[6] Sigal GB, Segal MR, Mathew A, et al. Biomarkers of tuberculosis severity and treatment effect: a directed screen of 70 host markers in a randomized clinical trial. EBioMedicine 2017;25:112-21.

[7] Scriba TJ, Penn-Nicholson A, Shankar S, et al. Sequential inflammatory processes define human progression from M. tuberculosis infection to tuberculosis disease. PLoS Pathog 2017;13(11):e1006687.

[8] Cliff JM, Lee JS, Constantinou N, et al. Distinct phases of blood gene expression pattern through tuberculosis treatment reflect modulation of the humoral immune response. J Infect Dis 2013;207(1):18-29.

[9] Esmail H, Lai RP, Lesosky M, et al. Complement pathway gene activation and rising circulating immune complexes characterize early disease in HIV-associated tuberculosis. Proc Natl Acad Sci U S A 2018;115(5):E964-73.

[10] Cai Y, Yang Q, Tang Y, et al. Increased complement C1q level marks active disease in human tuberculosis. PloS One 2014;9(3):e92340.

[11] Benoit ME, Clarke EV, Morgado P, et al. Complement protein $\mathrm{C} 1 \mathrm{q}$ directs macrophage polarization and limits inflammasome activity during the uptake of apoptotic cells. J Immunol 2012;188(11):5682-93.

[12] Nayak A, Pednekar L, Reid KB, et al. Complement and noncomplement activating functions of $\mathrm{C} 1 \mathrm{q}$ : a prototypical innate immune molecule. J Innate Immun 2012;18(2):350-63.

[13] Bohlson SS, Fraser DA, Tenner AJ. Complement proteins $\mathrm{C} 1 \mathrm{q}$ and MBL are pattern recognition molecules that signal immediate and long-term protective immune functions. Mol Immunol 2007;44(1-3):33-43. 
[14] Jagannath C, Hoffmann H, Sepulveda E, et al. Hyper susceptibility of A/J mice to tuberculosis is in part due to a deficiency of the fifth complement component (C5). Scand J Immunol 2000;52(4):369-79.

[15] Manivannan S, Rao NV, Ramanathan VD. Role of complement activation and antibody in the interaction between Mycobacterium tuberculosis and human macrophages. Indian J Exp Biol 2012;50(8):542-50.

[16] Lubbers R, Sutherland JS, Goletti D, et al. Complement component $\mathrm{C} 1 \mathrm{q}$ as serum biomarker to detect active tuberculosis. Front Immunol 2018;9:2427.
[17] Beurskens FJ, van Schaarenburg RA, Trouw LA. C1q, antibodies and anti-C1q autoantibodies. Mol Immunol 2015;68(1):6-13.

[18] Suliman S, Thompson EG, Sutherland J, et al. Four-gene pan-African blood signature predicts progression to tuberculosis. Am J Respir Crit Care Med 2018;197(9):1198-208. 